ammonia levels, for many months.

A very different approach to the control of ammonia levels has been introduced by Brusilow et al. 7,22. Sodium benzoate and phenylacetic acid are excreted in urine after conjugation with the nitrogen-containing compounds glycine and glutamine respectively. A patient with partial CPS deficiency was given $6 \mathrm{~g}$ sodium benzoate, and then $6 \mathrm{~g}$ of phenylacetate. On each occasion, urinary nitrogen excretion increased by approximately 50 per cent and blood ammonia levels (which were within the normal range whilst the patient was receiving a low-protein diet) and glutamine levels fell. Four patients in coma due to ammonia intoxication were given $200-350$ $\mathrm{mg}$ per $\mathrm{kg}$ of sodium benzoate intravenously and again blood ammonia levels fell, this time from 100 times normal to near normal.

It seems that with a combination of therapeutic strategies long-term treatment of the severe forms of urea cycle disorder is becoming possible ${ }^{23}$. Nevertheless, many patients remain at risk of sudden onset of hyperammonaemic coma, due to infection or dietary indiscretion, and the incidence of sudden death remains high. Prompt treatment of infections and avoidance of catabolism by ensuring an adequate energy intake at all times is an important element of long-term treatment ${ }^{24}$. Peritoneal or haemodialysis, in skilled hands, effectively removes excess ammonia when other measures fail but these procedures need to be started before irreversible brain damage has occurred. The demands which these advances in treatment make on medical services and the families involved are great, and much more information is needed about long-term survival, intellectual progress and social adjustment before the real impact of these developments can be assessed.

1. Shih, E. in The Metabolic Basis of Inherited Disease (eds Stanbury, J.B., Wyngaarden, J. B. \& Fredrickson, D. S.) 362 (McGraw Hill, New York, 1978).

2. Levin, B. \& Russell, A. Am. J. Dis. Child 113, 142 (1967).

3. Snyderman, S. E. et al. Pediatrics 56, 65 (1976)

4. Walser, M. et al Clin Sci molec. Med 53, 173 (1977).

Batshaw, M. L., Brusilow, S. \& Walser, M. Pediatrics 58. 227 (1976).

Brusilow, S. W. \& Batshaw, M. L. Lancet i, 134 (1979).

7. Brusilow, S. W., Valle, D. L. \& Barshaw, M. L. Lancet ii, 452 (1979).

8. Batshaw, M. L. \& Brusilow, S. W. J. Pediat. 97, 893 (1980)

9. Wiegard, C. et al. J. Pediat, 96, 142 (1980).

10. Snyderman, S. E. et al. J. Pediat. 95, 61 (1979).

11. Visek, W. J. Nutr. Rev. 37, 273 (1979).

II. Visek, W. J. Nutr. Rev. 37, 273 (1979). (1980).
Oyanagi, K. et al. J. Pediat. 94, 255 (1979).

3. Oyanagi, K. et al. J. Pediat. 94,255 (1979).

4. Valle, D., Walser, M. \& Brusilow, S. W. J.clin.Invest. 65 371 (1980).

15. Hommes, F. A. et al. Rep. int. Symp. on Metabolic Disease, Interlaken (1980).

16. Collins, F. S. et al. J. Pediat, 96, 429 (1980)

17. Bachmann, C. \& Colombo, J. P. Eur. J. Pediat. 134, 109 (1980).

18. Stewar1, P. M. \& Walser, M. J.biol. Chem. 255, 5270 (1980)

19. Close, J. H. New Engl. J, Med. 290, 663 (1974).

20. McReynolds, J. W. et al. J. Pediat. 93421 (1978)

21. Thoene, S. et al. J. Pediat. 90, 213 (1977).

22. Brusilow, S., Tinker, J. \& Batshaw, M. I. Lancet ii, 432 (1979).

23. Brusilow, S., Thomas, G. H. \& Brusilow, S. W. Pap. at Meet. on Inborn Errors of Metabolism, Florida (1980).

24. Smith, I. \& Francis, D. E. M. in Textbook of Paediatric Nutrition (eds McLaren, D. \& Burman, D.) 273 (Churchill Livingstone, 1976).

\title{
Late-glacial climatic changes
}

\section{from Peter Moore}

CONSIDERABLE interest and controversy surround the climatic events at the close of the last glaciation. In north-west Europe, the warming which began at around 13,500 $\mathrm{BP}$ was interrupted by one major cold phase (at about 11,000-10,000 BP) and one less severe event (at about 12,000-11,800 BP) (dates according to Mangerud et al. Boreas $3 ; 109,1974)$. Both of these cold episodes are clearly expressed in the physical nature of lake sediments and in the contained pollen assemblages of sites in mainland north-west Europe, such as Denmark; but the earlier cold phase is not well marked either sedimentologically or palynologically in British sites, especially western ones. This has led Pennington (Boreas 4; 157, 1975) to define a single 'Windermere' interstadial for the British Isles, effectively encompassing the time covered by the two continental interstadials.

Moving further east and south across Europe, one finds that the evidence for this complex of climatic oscillations is weaker, and the amplitude of the climatic fluctuations is evidently dampened. Watts (in Studies in the Late-Glacial of North-West Europe (eds J.J. Lowe, J.M. Gray \& J.E. Robinson) Pergamon Press, Oxford; 1980) claims that there is no Alpine site which clearly supports a double oscillation of climate in the late-glacial and that even the major cold phase (the 'Younger Dryas' of northern Europe) may be difficult to define, though it is often marked by an opening of Pinus cembra and Larix forest and an invasion of Juniperus and Artemisia. Soil erosion at the time may also be reflected in an increased input of minerogenic sediments into lake basins. Data from the Mediterranean area and south-west Europe for the late-glacial period are still rather scanty and open to a variety of interpretations.

On the other side of the Atlantic, there have been pollen diagrams from North America which suggest a late-glacial (Wisconsin) climatic oscillation. Perhaps the best known of these is that of Schweger (Ecology 50; 859, 1969) in which a Picea and Fraxinus-dominated early stage of forest development is interrupted by a period in which the arboreal/non-arboreal pollen ratio falls and Artemisia increase. The warm phase, dated at 11,640 BP, has been termed the 'Two Creeks Interstadial' and geomorphological evidence shows that there were minor extensions and contractions of the ice sheet at the closing stages of the Wisconsin glaciation (Wright Geol. Soc. Am. Mem. 136; 251, 1973). Some of the most detailed pollen data for this period have come from the work of Birks at Wolf Creek in Minnesota (Ecol. Monogr. 46; 395, 1976). He has demonstrated the existence, between 20,500 and $14,700 \mathrm{BP}$, of tundra vegetation which was invaded by dwarf shrub with willow and alder, and then at about 13,600 BP, Picea became the dominant pollen type. Between 13,600 and 10,000 BP there was no evidence for substantial change in the vegetation, but invasion by Pinus subsequently followed. So, the climatic changes which resulted in movement of the residual ice front over that late-Wisconsin time period in Minnesota did not cause marked fluctuations in the vegetation around Wolf Creek. Birks considers it likely that the climatic thresholds necessary to cause such changes were not crossed. The inertia and inherent stability of the spruce forest evidently withstood the climatic oscillations, though their effect seems to have been felt more evidently in Schweger's site at Iola Bog, Wisconsin.

In the other direction, a pollen diagram from the Peking district of China (Kong and Du Acta bot. sinica 22; 330, 1980), covering the period of about 30,000-10,000 BP, permits an examination of late-glacial events in central Asia. In the basal sediments (older than 22,700 BP) Artemisia, Chenopodiaceae and Gramineae dominate, indicating a cold, arid steppe-tundra. At about 13,000 BP Abies, Picea and Pinus expand and Artemisia contracts, as gymnospermdominated forests invaded the Peking plain. By 11,850 Tilia (a taxon demanding warmth) begins to expand, and the authors suggest this point as the base of the 'Holocene'. But before a radiocarbon date of $10,750 \mathrm{BP}$, there are two marked peaks in the pollen of Artemisia, the first being accompanied by Thalictum and the second by Chenopodiaceae. It is tempting to interpret these as times of reversal in the trend towards warmer climate, permitting once again the temporary extension of the steppe-tundra herbs.

The late-glacial climatic oscillation is not a European anomaly, as was once sug gested by Mercer (Arctic \& Alpine Res. 1; 227,1969 ), though it does seem to be both more marked and more consistently recorded in north-west Europe than elsewhere. This may, in part, be due to the current paucity of information from many areas of southern Europe and Asia. Attempts to correlate warm and cold episodes over wide geographical areas are frustrated by the complexity of sequences, local variations in the record (perhaps a consequence of the threshold problem) and, not least, by the inherent errors in the radiocarbon dating of sediments.

Peter Moore is in the Department of Plant Sciences, University of London King's College 